\title{
Quantitative Evaluation of Somatotrophic Cells (SC) in the Adenohypophysis of Normal and Diabetic Male Chinese Hamsters
}

\author{
P. Deslex* and G. L. Rossi \\ Institut für Tierpathologie, Universität Bern, Bern, Switzerland
}

\begin{abstract}
Summary. The pituitary of genetically diabetic Chinese hamsters contains significantly $(\mathrm{p}<0.001)$ greater numbers of somatotrophes than pituitary of nondiabetics. This may play a role in the aetiopathology of diabetes in this species or at least contribute to the maintenance of hyperglycaemia.
\end{abstract}

Key words: Congenital diabetes, Chinese hamsters, pituitary histology, somatotrophes, quantitative evaluation, aetiology.

The possible significance of somatotrophin in the aetiology of juvenile diabetes has been emphasized increasingly in recent years $[3,22,23]$. In man, however, determinations of plasma basal levels of somatotrophin have not given consistent results [18, $25,29]$. After exercise, plasma somatotrophin levels of juvenile diabetics were significantly elevated [10, 24, 26].

Great differences in pituitary cell population have been found in diabetic patients both by earlier and more recent authors, as reported by Warren et al. in their extensive review on the subject [36]. Pituitaries of patients with juvenile diabetes, however, seem to have increased numbers of eosinophilic cells $[19,34]$.

The diabetogenic action of somatotrophin in experimental diabetes is firmly established. A relationship between hypophyseal secretion and diabetes was demonstrated before $1940[7,13,14,40]$; in 1949, the hyperglycaemic action of hypophyseal extracts was shown to depend upon somatotrophin $[4,15]$. Subsequent investigations confirmed this relationship [1, $16,17,21]$.

\footnotetext{
* Present address: Department of Experimental Medicine, Hoff-
} mann-La Roche \& Cie. Ltd., Basel, Switzerland
We have, therefore, compared in an animal model the numbers of somatotrophes (SC) in the adenohypophyses of normal and juvenile diabetic subjects. For this purpose, we have chosen the Chinese hamster (Cricetulus griseus), since the spontaneous and hereditary diabetes mellitus of this species is considered closely related to juvenile diabetes of man [30]. Occurrence of diabetes in the Chinese hamster is determined by four recessive genes [2]. Symptoms are, as in man, rather heterogeneous: animals may present only intermittent glycosuria, undergo ketotic decompensation, but never become obese [33]. The literature on this species is relatively abundant from both morphological and metabolic points of view.

Comprehensive reviews were presented by Weihe and Isenbügel [37] and Wappler and Fiedler [35]. The studies of Grodsky et al. [9], Hepp et al. [11], and Wilander [38] are among the most recent contributions.

\section{Material and Methods}

In a pilot study to determine the distribution of $\mathrm{SC}$, one hypophysis from a diabetic hamster was fixed by glutaraldehyde perfusion [31] as follows: under Nembutal anaesthesia the abdomen of the animal was opened, a hypodermic needle introduced into the abdominal aorta, the vena cava severed and the body perfused at physiological pressure with Ringer's solution for 2 minutes, followed by $2.5 \%$ phosphate-buffered $(\mathrm{pH} 7.5)$ glutaraldehyde solution for $15 \mathrm{mi}-$ nutes, after which the pituitary was quickly removed. Post-perfusion fixation was also in glutaraldehyde (12 hours). After rinsing with phosphate buffer (410 $\operatorname{mos} / \mathrm{kg}$ ) the tissue was post-fixed for 1 hour in $1 \%$ osmium tetroxide solution, dehydrated in ethanol, infiltrated, oriented and embedded in Epon 312 for 


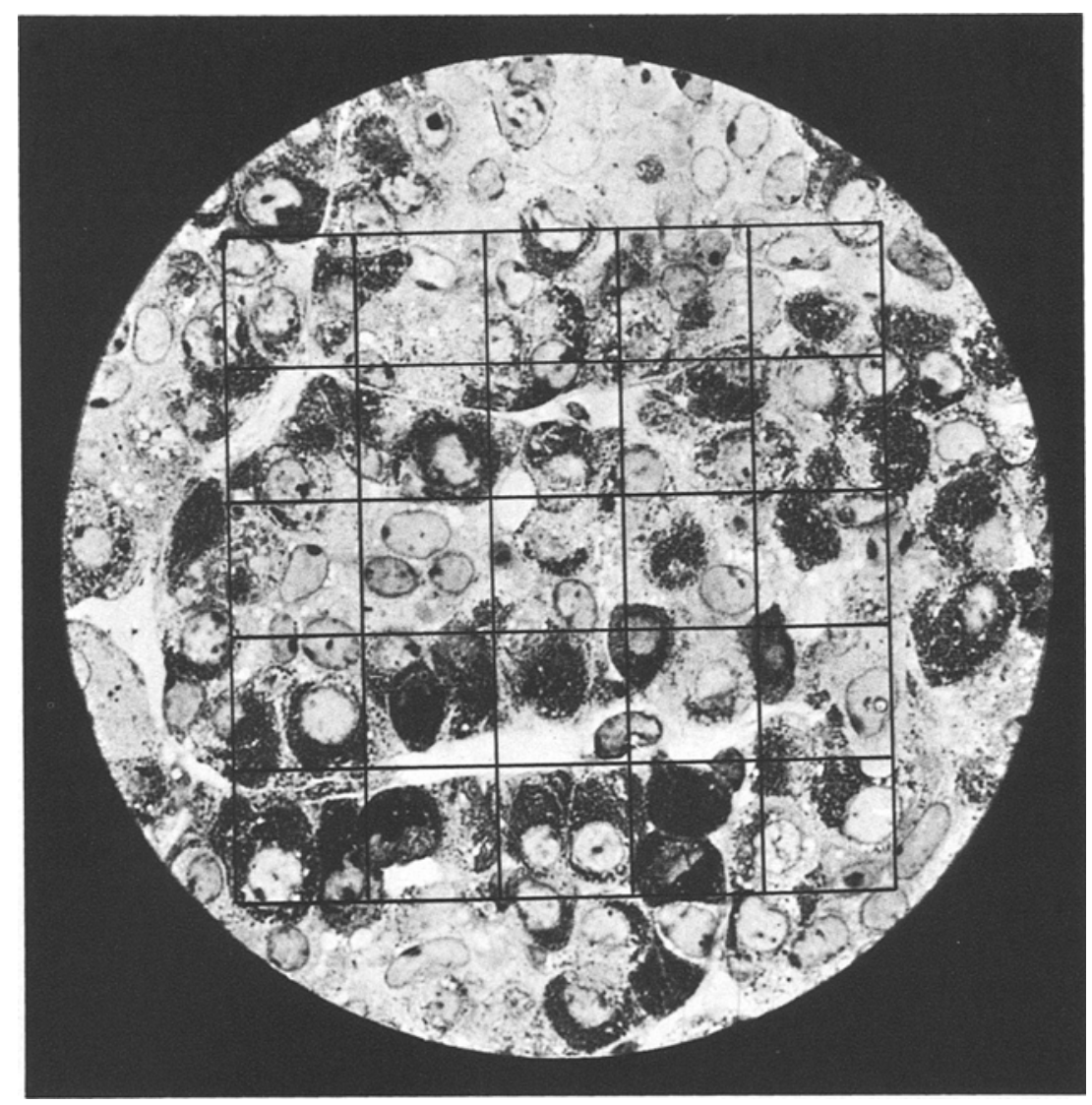

Fig. 1. Cytoscope screen with microscopic field, showing grid with subdivisions (10000 $\mu^{2}$ ). The secretory granule storing, darkly stained, ovoid cells are somatotrophes

sagittal sections. The entire hypophysis was then cut serially at $2.5 \mu$. Sections at $90 \mu$ intervals were mounted and stained with Toluidin-blue. The $36 \mathrm{sec}-$ tions so obtained were examined with the aid of a Zeiss "cytoscope" (projection microscope, $1000 \times$ ) in which each field defined and enclosed $10000 \mu^{2}$. Each section, scanned and counted, field by field, gave values from which mean numbers of SC per unit field could be calculated. Fields per section ranged from 80 to 100 .

In the main experiment we have examined hypophyses from 22 males, aged approximately 1 year, 11 with spontaneous diabetes and 11 normals of comparable body weight ${ }^{1}$. Normals were from a colony that had not given evidence of diabetes during a 5-year observation period. Urine was checked for glucose once a week $\left(\right.$ Testape $\left.^{\circledR}\right)$. Diabetics developed glycosuria at age 3 months, with values from ++ to ++++ . For the final tests, blood was obtained from the jugular vein and urine, after the abdomen was

\footnotetext{
All animals were derived initially from a colony of the Upjohn Company, Kalamazoo, Michigan. For this study, diabetics were supplied by Dr. Beglinger, Institut für Tierzucht, University of Zürich, controls by the Institut für biologisch-medizinische Forschung AG, Füllinsdorf, Switzerland.
}

opened, directly from the bladder. Determinations, based on duplicate samples, revealed a glycaemia of $380 \pm 51 \mathrm{mg} / 100 \mathrm{ml}$ blood $(\overline{\mathrm{x}} \pm \mathrm{SE}$ of controls $115 \pm$ 1.3; GOD-Perid ${ }^{\circledR}$ ) and absence of acetonuria (Acetest $^{\circledR}$ ). All animals were perfused and pituitaries processed as for the pilot experiment. Since in this, distribution of SC proved to be highly uniform throughout the adenohypophysis, their numbers in controls and diabetics were compared by counts of only one sagittal section taken lateral to the neurohypophysis. The significance of the difference between number of SC of controls and diabetics was calculated by means of an analysis of variance.

\section{Results}

Fig. 1 illustrates a characteristic field from a Toluidinblue stained section. The square grid conveniently fits into the microscopic field, which it divides into 25 smaller squares, each enclosing one or two SC, recognized by their darkly stained secretory granules, more or less circular forms and relatively large nuclei, as we had previously established by electron microscopy [5]. 


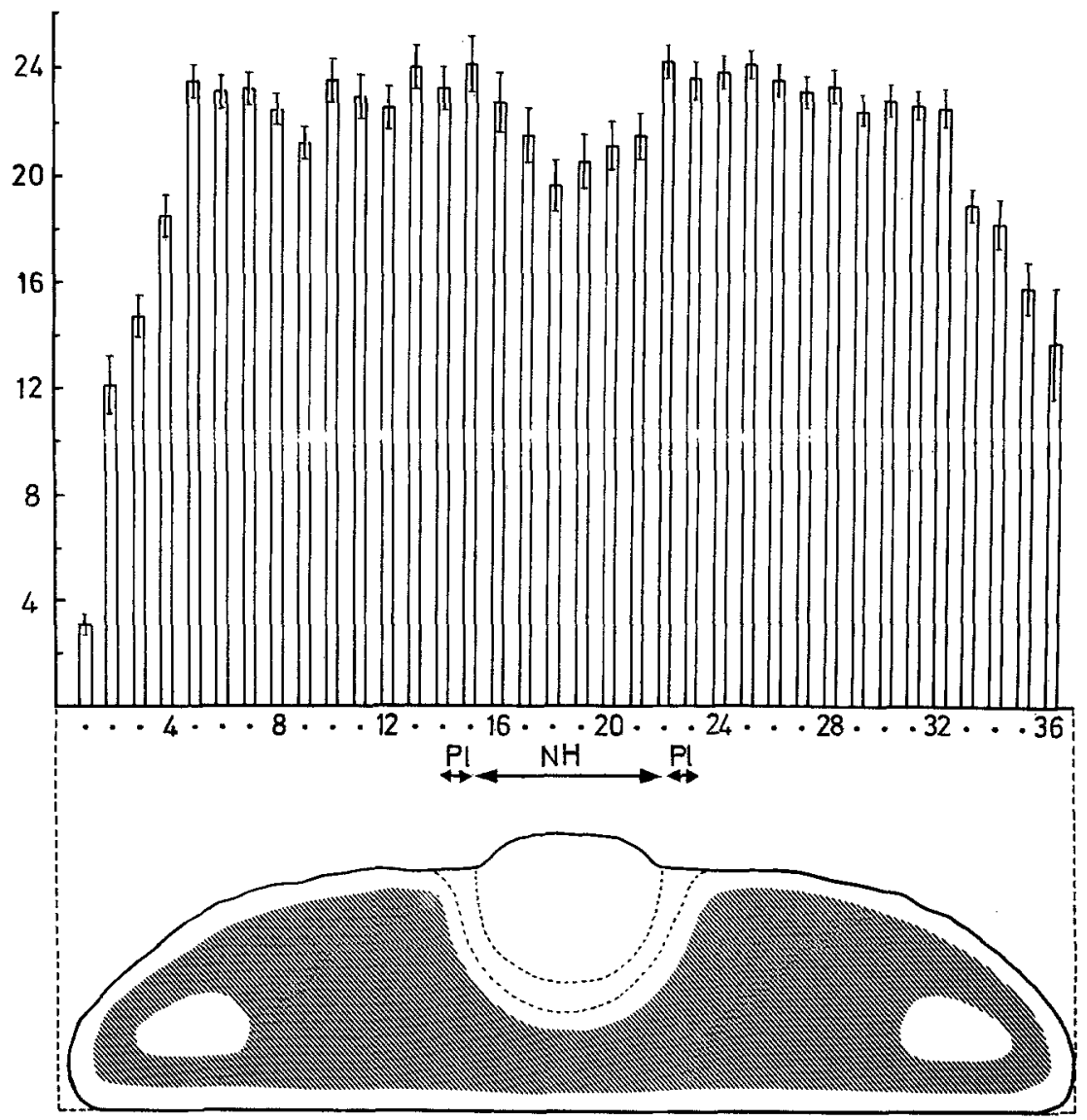

Fig. 2, Graph with vertical columns representing mean densities and standard errors of SC in 36 histological sections, located as shown and spaced at $90 \mu$. Outline of dorso-ventral section through midportion of the hypophysis of a Chinese hamster. Neural and intermediate lobes are indicated by dotted outlines. The adenohypophyseal area in which SC are uniformly distributed is indicated with diagonal lines within a clear periphery and clear inner zones at both ends. $\mathrm{SC}$ are less numerous in clear peripheral and innerzones

\section{Pilot Study}

The lower half of Fig. 2 illustrates the relatively uniform distribution of $\mathrm{SC}$ in a series of sagittal sections through the adenohypophysis of a diabetic hamster. Only the periphery and the zone immediately adjacent to the intermediate lobe contain less SC. This result corresponds closely to the distribution of $\mathrm{SC}$ in rats as observed by immunohistochemistry [27]. On the upper half of Fig. 2 each vertical column represents the mean of 80 to 100 fields in one $2.5 \mu$ section taken at $90 \mu$ intervals throughout the gland. Standard errors for each column demonstrate the uniformity of distribution within each section. The similarity of the absolute values in the region lateral to the neurohypophysis permitted counting of SC for the comparative study from a single section taken in this region.

\section{Main Investigation}

Table 1 lists body weights for control and diabetic hamsters with corresponding means and standard errors for SC for each. Mean numbers ( \pm SE) of SC per $10000 \mu^{2}$ was $16.5 \pm 0.79$ for controls and $23.5 \pm 0.52$ for the diabetics, or a $42.5 \%$ greater number of SC in the adenohypophysis of the diabetics. This difference was highly significant $(\mathrm{p}<0.001)$.

\section{Discussion}

Perfusion fixation was used since it ensures essentially immediate fixation to preserve cellular outlines, densities and internal structures [5, 28, 31]. The preliminary rinsing with Ringer also removed erythrocytes, which stain strongly by Toluidin-blue and confuse SC recognition. We prefer Toluidin-blue that stains acidophils intensively to the Trichrome methods $[6,8$, 12] for cell identification, since the latter have not given reliable results in our studies of rodent pituitaries. Since males were used, the hypophyses contained only a few mammotropes, which, being acidophils, might be confused with SC. These latter were also recognized by their round or ovoid form and high density secretory granules in their vascular pole [5]. The low standard error for each animal supports our claim of an uniform distribution of $\mathrm{SC}$ within the selected region of the adenohypophysis.

The increased numbers of SC found in diabetic 
Table 1. Individual values of body weights and numbers of somatotrophes per $10000 \mu^{2}$, with means and standard errors for 11 control and 11 diabetic Chinese hamsters

\begin{tabular}{|c|c|c|c|c|}
\hline \multirow{3}{*}{$\begin{array}{l}\text { Animal } \\
\text { No. }\end{array}$} & \multicolumn{2}{|l|}{ Controls } & \multicolumn{2}{|l|}{ Diabetics } \\
\hline & Body weight & Somatotrophes & Body weight & Somatotrophes \\
\hline & gr. & $\overline{\mathrm{x}} \pm \mathrm{SE}$ & gr. & $\bar{x} \pm \mathrm{SE}$ \\
\hline 1 & 33 & $17.81 \pm 0.65$ & 36 & $22.00 \pm 0.62$ \\
\hline 2 & 32 & $14.63 \pm 0.68$ & 40 & $24.14 \pm 0.54$ \\
\hline 3 & 41 & $22.12 \pm 0.68$ & 44 & $25.68 \pm 0.66$ \\
\hline 4 & 41 & $18.75 \pm 0.65$ & 43 & $23.27 \pm 0.71$ \\
\hline 5 & 37 & $15.58 \pm 0.58$ & 42 & $23.76 \pm 1.09$ \\
\hline 6 & 38 & $12.34 \pm 0.59$ & 39 & $22.01 \pm 0.85$ \\
\hline 7 & 32 & $16.62 \pm 0.56$ & 34 & $25.86 \pm 0.81$ \\
\hline 8 & 30 & $17.80 \pm 0.53$ & 44 & $20.99 \pm 0.74$ \\
\hline 9 & 42 & $16.96 \pm 0.62$ & 36 & $21.55 \pm 0.73$ \\
\hline 10 & 36 & $14.24 \pm 0.43$ & 44 & $25.55 \pm 0.66$ \\
\hline 11 & 36 & $15.01 \pm 0.64$ & 18 & $24.26 \pm 0.89$ \\
\hline
\end{tabular}

Average $36.2 \pm 1.2 \quad 16.53 \pm 0.79 \quad 38.2 \pm 2.3 \quad 23.55 \pm 0.52$ \pm SE

hamsters may be explained either as a retrogressive response to the hyperglycaemia in diabetes, as assumed for the KK mouse [39], or a sign of hyperactivity.

In the first case, since diabetes had existed for more than 6 months, growth hormone secretion should have been suppressed and the many SC present should be in the storage phase as large cells filled with granules, or in a later stage with increased numbers of lysosomes and signs of autophagocytosis. Our electron microscopic study has found, however, both storage and secretory SC but no sign of autophagocytosis [32]. Moreover, the hyperglycaemia itself should not stimulate a multiplication of SC.

In the second case, we would deal with a hyperfunction of SC in diabetic hamsters, which would cause an increase of plasma somatotropin levels. At the onset of the disease, such an increase could explain both hyperglycaemia and hyperinsulinaemia, observed by Like and coworkers [20], as well as the normoglycaemia and hyperinsulinaemia found by the same authors in animals with spontaneous remissions. The significance of the hyperfunction of SC for the physiopathology of diabetes in the Chinese hamster must be investigated further.

\section{References}

1. Bornstein, J., Armstrong, J.McD., Taft, H.P., Ng, F. M., Gould, M.K.: The mechanism of the diabetogenic effects of pituitary growth hormone. Postgrad. med. J. 49, 219-242 (1973)

2. Butler, L., Gerritsen, G.C.: A comparison of the modes of inheritance of diabetes in the Chinese hamster and the KK mouse. Diabetologia 6, 163-167 (1970)

3. Campbell, J.: Diabetogenic actions of growth hormone. In: The hypophyseal growth hormone, nature and actions (eds. R.W. Smith, O.H. Gaebler, C.N.H. Long), p. 270. New York: McGraw-Hill, Blakiston Division 1955

4. Cotes, P.M., Reid, E., Young, F.G.: Diabetogenic action of pure anterior pituitary growth hormone. Nature 164, 209-211 (1949)

5. Deslex, P., Rossi, G.L., Probst, D.: Ultrastructural study of the adenohypophysis of the Chinese hamster. Acta anat. (Basel) (in press 1976)

6. El Etreby, M.F., Tüshaus, U.: Differentialfärbung zur Darstellung von Wachstumshormon und Prolaktin produzierenden Zellen des Hypophysenvorderlappens. Histochemie 33, 121-127 (1973)

7. Evans, H.M., Meyer, K., Simpson, M.E., Reichert, F.L.: Disturbance of carbohydrate metabolism in normal dogs injected with the hypophyseal growth hormone. Proc. Soc. exp. Biol. (N.Y.) 29, 857-858 (1932)

8. Gomori, G.: Staining of chromaffin tissue. Amer. J. clin. Path. 10, 115-117 (1946)

9. Grodsky, G.M., Frankel, B.J., Gerich, J.E., Gerritsen, G. C.: The diabetic Chinese hamster: In vitro insulin and glucagon release; the "chemical diabetic"; and the effect of diet on ketonuria. Diabetologia 10, 521-528 (1974)

10. Hansen, A.P.: Abnormal serum growth hormone response to exercise in juvenile diabetics. J. clin. Invest. 49, 1467-1478 (1970)

11. Hepp, K.D., Langley, J., von Funcke, H.L., Renner, R., Kemmler, W.: Increased insulin binding capacity of liver membranes from diabetic Chinese hamsters. Nature 258, 154 (1975)

12. Herlant, M.: Etude critique de 2 techniques nouvelles destinées à mettre en évidence les différentes catégories cellulaires présentes dans la glande pituitaire. Bull. Micr. appl. 10, 37-44 (1960)

13. Houssay, B.A., Magenta, M.A.: Sensibilité des chiens hypophysectomisés à l'égard de l'insuline. C.R. Soc. Biol. (Paris) 92, 822-824 (1925)

14. Houssay, B.A., Biasotti, A.: The hypophysis, carbohydrate metabolism and diabetes. Endocrinology 15, 511 (1931)

15. Houssay, B. A., Anderson, E.: Diabetogenic action of purified anterior pituitary hormones. Endocrinology 45, 627-629 (1949)

16. Ikkos, D., Luft, R.: "Idiohypophyseal" diabetes mellitus in two hypophysectomised women. Lancet 1960a II, 897-899

17. Ikkos, D., Luft, R.: Studies of the metabolic action of human growth hormone. Acta endocr. (Kbh.) 34, 83-84 (1960b)

18. Johansen, K., Hansen, H.P.: High 24-hour level of serum growth hormone in juvenile diabetics. Brit. med. J. 1969 II, 356-357

19. Labbé, M., Petresco, M.: Les altérations des glandes endocrines dans le diabète sucré. Ann. Anat. path. 11, 761-786 (1934)

20. Like, A.A., Gerritsen, G.C., Dulin, W.E., Gandreau, P.: Studies in the diabetic Chinese hamster: Light microscopy and autoradiography of pancreatic islets. Diabetologia 10, 501-508 (1974)

21. Luft, R., Cerasi, E.: Effect of human growth hormone on insulin production in panhypopituitarism. Lancet 1964 II, 124-126

22. Luft, R., Cerasi, E.: Human growth hormone as a regulator of blood glucose concentration and as a diabetogenic substance. Acta endocr. (Kbh.) Suppl. 124, 9-16 (1967)

23. Luft, R., Guillemin, R.: Growth hormone and diabetes in man. Old concepts - new implications. Diabetes 23, 783-787 (1974)

24. Lundbaek, K., Christensen, N.J., Jensen, V.A., Johansen, K., Olsen, T.S., Hansen, A.P., Ørskov, H., Østerby, R.: Diabetes, diabetic angiopathy, and growth hormone. Lancet 1970 II, 131-133

25. Molnar, G.D., Ackerman, E., Rosevear, J.W., Gatewood, L.C., Moxness, K.E.: Continuous blood glucose analysis in 
ambulatory fed subjects. I. General methodology, Proc. Mayo Clin. 43, 833-851 (1968)

26. Molnar, G.D., Taylor, W.F., Langworth, A., Fatourechi, V.: Diurnal growth hormone and glucose abnormalities in unstable diabetics: Studies of ambulatory fed subjects during continuous blood glucose analysis. J. clin. Endocr. 34, 837--846 (1972)

27. Nakane, P.K.: Classifications of anterior pituitary cell types with immunoenzyme histochemistry. J. Histochem. Cytochem. 18, 9-20 (1970)

28. Nouet, G.C., Kujas, M.: Influence de la méthode de fixation sur l'observation des divisions cellulaires dans l'adénohypophyse du rat male. Z. Zellforsch. 143, 535-547 (1973)

29. Parker, D.C., Rossman, L. G.: Sleep release of human growth hormone in treated juvenile diabetics. Similarity to normal subjects and non suppression by hyperglycemia. Diabetes $\mathbf{2 0}$, 691-695 (1971)

30. Renold, A.E., Burr, I.: The pathogenesis of diabetes mellitus. Possible usefulness of spontaneous hyperglycemic syndromes in animals. Calif. Med. 112, 23-24 (1970)

31. Rossi, G.L.: Simple apparatus for perfusion fixation for electron microscopy. Experientia (Basel) 31, 998-1000 (1975)

32. Rossi, G.L., Deslex, P.: Der chinesische Hamster als Tiermodell für Diabetes mellitus. III. Ultrastruktur der Hypophyse normaler und diabetischer Tiere. Berl. Münch. tierärztl. Wschr. 87, (Abstr.) 460-461 (1974)

33. Stauffacher, W., Orci, L., Cameron, D.P., Burr, I. M., Renold, A.E.: Spontaneous hyperglycemia and/or obesity in laboratory rodents: An example of the possible usefulness of animal disease models with both genetic and environmental components. Recent Progr. Hormone Res. 27, 41-95 (1971)

34. Steiner, H.: Quantitative und qualitative Zellveränderungen im
Hypophysenvorderlappen bei Diabetes mellitus. Virchows Arch. Abt. A Path. Anat. 339, 171-186 (1965)

35. Wappler, E., Fiedler, H.: Der Chinesische Hamster (Cricetulus griseus): Ein an Spontandiabetes erkrankendes Tier. Z. Versuchstierk. 14, 1-16 (1972)

36. Warren, Sh., Le Compte, P.M., Legg, M.A.: The pathology of diabetes mellitus, 4 th ed., p. 339. Philadelphia: Lea \& Febiger 1966

37. Weihe, W.H., Isenbügel, E.: Bibliographie über den Chinesischen Hamster. Z. Versuchstierk. 12, 115-129 (1970)

38. Wilander, E.: Streptozotozin-diabetes in the Chinese hamster. Volumetric quantification of the pancreatic islets and inhibition of diabetes with nicotinamide. Horm. Metab. Res. 7, 15-19 (1975)

39. Yamada, K., Nakamura, M., Yamashita, K.: Light and electron microscopic studies on the adenohypophysis of a diabetic (KK) strain of the mouse. Z. Zellforsch. 79, 429-445 (1967)

40. Young, F.G.: Permanent experimental diabetes produced by pituitary (anterior lobe) injections. Lancet 1937 II, 372-374

Received: February 26, 1976, and in revised form: June 21, 1976

Dr. G.L. Rossi

Universität Bern

Institut für Tierpathologie

Längasstraße 122

Postfach 2735

CH-3001 Bern

Switzerland 